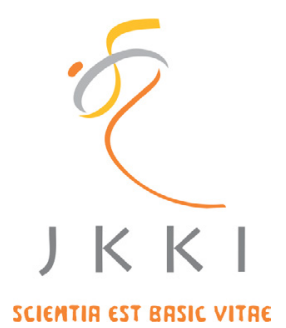

Jurnal Kedokteran dan Kesehatan Indonesia

Indonesian Journal of Medicine and Health

Journal homepage : www.journal.uii.ac.id/index.php/JKKI

\title{
Correlation between nurse knowledge and attitude with hand hy- giene compliance
}

\author{
Azhar Alwi Zakaria ${ }^{1}$, Liena Sofiana*1 \\ ${ }^{1}$ Student of Public Health, Faculty of Public Health, Universitas Ahmad Dahlan, Yogyakarta, Indonesia \\ ${ }^{2}$ Departement of Public Health, Faculty of Public Health, Universitas Ahmad Dahlan, Yogyakarta, Indonesia
}

Original Article

\begin{tabular}{|c|c|}
\hline & \\
\hline RTICLE INFO & \multirow{4}{*}{$\begin{array}{l}\text { Backround: World Health Organization (WHO) stated that nosocomial } \\
\text { infection cause } 1,4 \text { million death every day in the world in } 2010 \text {. Indonesia } \\
\text { has a high incidence of infection nosocomial within ten public hospitals in } \\
2010 \text {, where the rate was between } 6-16 \% \text { with an average } 9,8 \% \text {. Nurses } \\
\text { are expected to have the knowledge and attitude in the implementation of } \\
\text { hand hygiene because education and behavior are the factors involved in } \\
\text { performing hand hygiene } \\
\text { Objective: The purpose of this research is to determine the relationship } \\
\text { between nurses' knowledge and attitudes with hand hygiene compliance } \\
\text { in Nur Hidayah Hospital, Bantul. }\end{array}$} \\
\hline & \\
\hline & \\
\hline & \\
\hline & \multirow{2}{*}{$\begin{array}{l}\text { Methods: This research was an analytic observational study with the } \\
\text { cross-sectional design. The variable of this research is knowledge, attitude, } \\
\text { and hand hygiene compliance of nurses, with the } 40 \text { respondents. This } \\
\text { research used questionnaire and checklist sheet. Analysis of data was } \\
\text { done using analysis univariate and bivariate (Chi-square) test. } \\
\text { Result: The research indicated there was a connection between knowledge } \\
\text { and hand hygiene ( } \mathrm{P}=0,002 ; 95 \% \mathrm{CI}) \text { and also there is a connection } \\
\text { between attitude and compliance of hand hygiene (P=0,003;95\% CI) at } \\
\text { Nur Hidayah Bantul hospital. Those show that attitude is a risk factor. } \\
\text { Conclusion: There are connection between nurses' knowledge and } \\
\text { attitude with hand hygiene compliance at Nur Hidayah Bantul hospital. }\end{array}$} \\
\hline & \\
\hline
\end{tabular}

Latar Belakang: World Health Organization (WHO) menyebutkan bahwa infeksi nosokomial menyebabkan 1,4 juta kematian setiap hari di dunia pada tahun 2010. Di Indonesia, pada tahun 2010 ada 10 pendidikan rumah sakit umum yang terjadi pada kasus infeksi nosokomial yang tinggi yaitu 6-16\% dengan ratarata 9,8\%. Perawat diharapkan memiliki pengetahuan dan sikap yang tinggi baik dalam pelaksanaan kebersihan tangan karena pengetahuan dan sikap merupakan faktor risiko dalam melakukan kebersihan tangan. Tujuan penelitian ini adalah untuk mengetahui hubungan antara pengetahuan dan sikap dengan kepatuhan kebersihan tangan perawat di Rumah Sakit Nur Hidayah di Bantul.

Tujuan Penelitian: Tujuan penelitian ini adalah untuk mengetahui hubungan antara pengetahuan dan sikap perawat dengan kepatuhan kebersihan tangan di Rumah Sakit Nur Hidayah, Bantul.

Metode: Jenis penelitian ini adalah observasional analitik dengan desain cross sectional. Variabel penelitian ini adalah sikap pengetahuan dan kepatuhan kebersihan tangan perawat dengan jumlah responden 40. Instrumen penelitian ini menggunakan kuesioner dan lembar daftar periksa. Analisis data menggunakan analisis uji univariat dan bivariat (Chi-square).

Hasil: Terdapat hubungan yang signifikan antara pengetahuan dan kebersihan tangan $(P=0,002 ; 95 \%$ CI) dan hubungan sikap dan kepatuhan kebersihan tangan ( $P=0,003 ; 95 \%$ CI) di RS Nur Hidayah Bantul. 
Hal ini menunjukkan bahwa variabel sikap adalah faktor risiko.

Kesimpulan: Terdapat hubungan yang bermakna antara pengetahuan dan sikap perawat dengan kepatuhan hand hygiene pada perawat di RS Nur Hidayah Bantul.

\section{INTRODUCTION}

Hospital, as a place of treatment, is also a health care facility that can be a source of infection. Nosocomial infections can occur in patients, health workers, and to everyone who comes to the hospital. Infections in health care center can be transmitted or obtained through health workers, patients, carrier status visitors, or because of hospital conditions. ${ }^{1}$ Prevention and control are the most significant challenges in health services. Increased cost to overcome healthcare-related infection is a big concern for patients and healthcare professionals. One simple step of eliminating these infections and other infections is proper hand washing. ${ }^{2}$

Hand hygiene significantly reduces the number of disease-causing microorganisms and minimizes cross-contamination. ${ }^{3}$ Hand washing is the initial and closing procedure performed by nurses in providing nursing care. This action can eliminate most of the microorganisms present in the skin. ${ }^{4}$ The recognition of the nurses themselves must also support the application of handwashing and awareness in carrying out the correct Standard Operational Procedure (SOP) for nurses, to protect themselves and even patients with the infectious material. The habit of handwashing in hospitals is a fundamental behavior in the effort of preventing cross infection. $^{5}$

In 2010 as many as ten general education hospitals in Indonesia recorded the incidence of nosocomial infections by $6-16 \%$ (mean 9.8\%). ${ }^{6}$ In developing countries like Indonesia, the rate of nosocomial infections is much higher. Nosocomial infections are high due to lack of supervision, poor prevention practices, inappropriate use of limited resources and overcrowded hospitals. Research conducted in two major cities in Indonesia shows that the incidence of nosocomial infections ranges from $39 \%-60 \%{ }^{7}$ A preliminary study showed that the majority of nurses did not follow the hand hygiene and washing procedure.

\section{METHODS}

This study is an observational analytic study with cross sectional approach. We used total sampling. The inclusion criteria were all nurse who worked in RS Nur Hidayah and willing to participate. Exclusion criteria were all nurse who were on leave. Fourty respondents who met the inclusion and exclusion criteria were analyzed. Instruments used in this research were questionnaire and checklist. Questionaire was used to measure the knowledge and attitude of the subjects. Knowledge Questionaire had Cronbach's alpha value 0,63 , which consist of 19 items, including 13 favourable questions and 6 unfavourable questions. For favourable questions, 1 is the score for yes and score 0 is for answering no. While for unfavourable questions, score 0 is for answering es and 1 is for opposites answer. If the total score was < average $(<17)$, subject was categorized as low knowedge. If the total score was $\geq$ average $(\geq 17)$, subject was classified as high.

Attitude questionnaire had Cronbach's alpha value 0,944 which consisted of 15 item, including 11 favourable questions and unfavourable questions. Favourable questions were scored 5 for highly agree (SS), 4 for agree (S), 3 for in doubt (R), 2 for disagree (TS), 1 for highly disagree (STS). And for unfavourable questions were scored 1 for highly agree (SS), 2 for agree (S), 3 for in doubt (R), 4 for disagree (TS), and 5 for profoundly disagree (STS). If the total score was < average, subjects get in as poor categorization $(<65)$, while if the score was $\geq$ average, subjects were categorized as good $(\geq 65$ ). The checklist was used to asses nurse's compliance on practicing hand hygiene based on SOP of Nur Hidayah Bantul hospital.

Statistical analysis was done using univariate and bivarate analysis. Bivariate analysis used was Chi-square test, in which independent variables were knowledge and attitude, while dependent 
variable was hand hygiene compliance. Statistical analysis using Chi-Square with Confident Interval (CI) 95\% significance $(\alpha=0,05)$.

Statistical analysis was done using univariat and bvarat analysis. Bivariat analysis used was chi-square test, in which independent variables were knowledge and attitude, while dependent variable was hand hygiene compliance. Statistial analysis using Chi-Square with Confident Interval (CI) 95\% significancy $(\alpha=0,05)$.

\section{RESULTS}

\section{Subject Demographic}

Subject demographic is presented in Table 1. The present study showed that female nurses have better compliance ( 21 of 32 female nurses $(65,6 \%)$ compared to male nurses $(62,5)$. The age group with better compliance is those $>30$ years old (100\%). All subjects graduated with a diploma, however, only 24 nurses had good hand hygiene compliance. Nurses with $\geq 2$ years of working experience had better compliance $(17$ perawat/ 63\%). Only 17 nurses from a total of 27 nurses who had joined nosocomial infection workshop, had good compliance $(65,4 \%)$.

Present study found that nurses with high knowledge (score $\geq 17$ ) were $23(57,5 \%)$, which is more than those with poor knowledge $(42,5 \%)$. Nurses with the good attitude (score $\geq 65$ ) were $25(62,5 \%)$ which is more than poor attitude $(37,5 \%)$. Nurses hand hygiene compliance in Nur Hidayah Bantul hospital who had good compliance with score $\geq 44$ were $24(60 \%)$, which is more than poor compliance (40\%) (Table 2).

Table 1. Subject demographic in Nur Hidayah Bantul hospital

\begin{tabular}{|c|c|c|c|c|c|}
\hline \multirow{2}{*}{ No } & \multirow{2}{*}{ Variable } & \multicolumn{4}{|c|}{ Compliance } \\
\hline & & \multicolumn{2}{|c|}{ Poor } & \multicolumn{2}{|c|}{ Good } \\
\hline \multirow[t]{3}{*}{1} & Gender & $\mathrm{N}$ & $\%$ & $\mathrm{~N}$ & $\%$ \\
\hline & a. Male & 3 & 37,5 & 5 & 62,5 \\
\hline & b. Female & 11 & 34,4 & 21 & 65,6 \\
\hline \multirow[t]{6}{*}{2} & Age & & & & \\
\hline & a. 22-24 years old & 5 & 71,5 & 2 & 28,6 \\
\hline & b. 25-27 years old & 6 & 33,3 & 12 & 66 \\
\hline & c. $28-30$ years old & 4 & 36,4 & 7 & 63,6 \\
\hline & d. 31-33 years old & 0 & 0 & 3 & 100 \\
\hline & e. 34-36 years old & 0 & 0 & 1 & 100 \\
\hline \multirow[t]{4}{*}{3} & Education & & & & \\
\hline & a. SPK & 0 & 0 & 0 & 0 \\
\hline & b. D3 & 16 & 40 & 24 & 60 \\
\hline & c. S1 & 0 & 0 & 0 & 0 \\
\hline \multirow[t]{3}{*}{4} & Working Experience & & & & \\
\hline & a. $<2$ Years & 6 & 56 & 7 & 54 \\
\hline & b. $\geq 2$ Years & 10 & 37 & 17 & 63 \\
\hline \multirow[t]{3}{*}{5} & Nosocomial infection workshop & & & & \\
\hline & a. Never & 7 & 50 & 7 & 50 \\
\hline & b. Yes & 9 & 34,6 & 17 & 65,4 \\
\hline
\end{tabular}


Table 2. Knowledge and Attitude with Hand Hygiene compliance of nurses Nur Hidayah Bantul hospital

\begin{tabular}{|c|c|c|c|}
\hline No & Variable & Total (n) & Percentage (\%) \\
\hline \multirow[t]{3}{*}{1} & Knowledge & & \\
\hline & a. Low & 17 & 42,5 \\
\hline & b. High & 23 & 57,5 \\
\hline \multirow[t]{3}{*}{2} & Attitude & & \\
\hline & a. Poor & 15 & 37,5 \\
\hline & b. Good & 25 & 62,5 \\
\hline \multirow[t]{4}{*}{3} & Hand Hygiene compliance & & \\
\hline & a. Poor & 6 & 40 \\
\hline & b. Good & 24 & 60 \\
\hline & Total & 40 & 100 \\
\hline
\end{tabular}

Correlation between Knowledge with Hand Hygiene Compliance

The results of statistical analysis using Chi- compliance in nurses Nur Hidayah Bantul hospital are as follow: Square between knowledge and hand hygiene

Table 3. Correlation between knowledge with hand hygiene compliance in nurses Nur Hidayah Bantul hospital

\begin{tabular}{|c|c|c|c|c|c|c|c|c|}
\hline \multirow{3}{*}{ Knowledge } & \multicolumn{4}{|c|}{ Compliance } & \multirow{2}{*}{\multicolumn{2}{|c|}{ Total }} & \multirow{3}{*}{$P$ value } & \multirow{3}{*}{$\begin{array}{c}\text { RP } \\
(95 \% \mathrm{CI})\end{array}$} \\
\hline & \multicolumn{2}{|c|}{ Poor } & \multicolumn{2}{|c|}{ Good } & & & & \\
\hline & $\mathbf{N}$ & $\%$ & $\mathbf{n}$ & $\%$ & $\mathbf{n}$ & $\%$ & & \\
\hline $\begin{array}{l}\text { Low } \\
(\text { mean <17) }\end{array}$ & 12 & 75 & 5 & 20,8 & 17 & 42,5 & & \\
\hline $\begin{array}{l}\text { High } \\
\text { (mean } \geq 17 \text { ) }\end{array}$ & 4 & 25 & 19 & 79,2 & 23 & 57,5 & 0,002 & $\begin{array}{c}4,059 \\
1,582-10,412\end{array}$ \\
\hline Total & 16 & 100 & 24 & 100 & 40 & 100 & & \\
\hline
\end{tabular}

Based on Table 3, nurses who had low knowledge and poor compliance were $75 \%$, which is larger than nurses who had high knowledge and poor compliance (25\%). Nurses who had low knowledge and good compliance were even less $(20,8 \%)$ compared to those who had high knowledge and good compliance $(79,2 \%)$. Subjects with low knowledge have 4,059 higher chances of poor compliance compare to those with the high level of knowledge (95\% CI: $1,582-10.412 p$-value $=0,002$ ). This result shows that knowledge affects hand hygiene compliance in Rumah Sakit Nur Hidayah Bantul.
The Correlation between Attitude and Hand Hygiene Compliance

Table 4 shows that nurses with poor attitude and compliance towards hand hygiene $(68,7 \%)$ were more than those who had good attitude but poor compliance $(31,25 \%)$. Nurses who had poor attitude but good hand hygiene $(16,7 \%)$ were less than those who had good attitude and compliance $(83,3 \%)$. Nurses who had poor attitude is 3,667 times higher risk of poor compliance compare to those with good attitude (95\% CI: $1,581-8,054$ p value $=0,003)$. This result showed that, attitude affects the compliance of 
Table 4. The Correlation between attitude with hand hygiene compliance of nurses in Nur Hidayah Bantul hospital.

\begin{tabular}{|c|c|c|c|c|c|c|c|c|}
\hline \multirow{3}{*}{ Knowledge } & \multicolumn{4}{|c|}{ Compliance } & \multirow{2}{*}{\multicolumn{2}{|c|}{ Total }} & \multirow{3}{*}{$P$ value } & \multirow{3}{*}{$\begin{array}{c}\text { RP } \\
(95 \% \text { CI) }\end{array}$} \\
\hline & \multicolumn{2}{|c|}{ Poor } & \multicolumn{2}{|c|}{ Good } & & & & \\
\hline & $\mathbf{N}$ & $\%$ & $\mathbf{n}$ & $\%$ & $\mathbf{n}$ & $\%$ & & \\
\hline $\begin{array}{l}\text { Poor } \\
(\text { Mean <65) }\end{array}$ & 11 & 68,75 & 4 & 16,7 & 15 & 37,5 & & \\
\hline $\begin{array}{l}\text { Good } \\
(\text { Mean } \geq 65)\end{array}$ & 5 & 31,25 & 20 & 83,3 & 25 & 62,5 & 0,003 & $\begin{array}{c}3,667 \\
1,581-8,504\end{array}$ \\
\hline Total & 16 & 100 & 24 & 100 & 40 & 100 & & \\
\hline
\end{tabular}

hand hygiene practice in Nur Hidayah Bantul hospital.

\section{DISCUSSION}

The present study shows a significant correlation between knowledge and hand hygiene compliance, which is a risk factor. Lower knowledge subjects are at 4,059 higher risks of having poor compliance compared to more top knowledge subjects. This is statistically significant $(95 \% \mathrm{CI}$; p-value $=0,002)$, so the conclusion is the knowledge affects hand hygiene compliance in Nur Hidayah Bantul hospital.

The analysis shows that there is a correlation between nurse's knowledge with hand hygiene compliance. The better understanding is affected by a lot of factors. The first factor is nurses' education level, in which the higher the level of education the better they comprehend information. Knowledge is closely related to education, where the better one's education the broader their insight is expected. On the contrary, the lower their education the less information is obtained. ${ }^{8}$ The present study shows, all subjects are diploma graduates, 24 nurses or $60 \%$ of the research subject complied to hand hygiene protocol. Education level also affects information comprehension, for instance when they were informed about five steps of hand hygiene protocol by WHO standard if the education level is better then they can receive and apply information better as well. ${ }^{9}$

The second factor is the length of work experience. Nurses with more extended working experience will have better knowledge of infection prevention because they are used to the hospital environment. The present study shows that nurses who have work for $\geq 2$ years have better hand hygiene compliance, in which 17 subjects or $63 \%$. The nurse who has worked for the longest time has better knowledge on the prevention of nosocomial infection in the hospital. ${ }^{9}$

The third factor is involved in the workshop. Workshops will enhance nurses' knowledge on the prevention of nosocomial infection. The present study shows that nurses who have to attend workshops are better at doing hand hygiene protocol, which is 17 more or $65,4 \%$. Training acts as a source of information, which can give broader insight into their way of thinking or the use of reasoning and critical thinking, therefore will increase their sense of problemsolving. The researcher argues that workshop is beneficial to support their knowledge of nosocomial infection. ${ }^{9}$

Table 3 showed that most nurses have good knowledge, in which from 17 nurses with poor knowledge only five $(20,8 \%)$ have good compliance on hand hygiene protocol. While from 23 nurses with good knowledge, only 19 nurses $(57,5 \%)$ have good compliance on hand hygiene protocol. Knowledge or cognition is an essential aspect of forming one's action. This knowledge can also affect one's behavior. ${ }^{10}$

Based on field analysis done with the Head of Infection Prevention and Control (Pencegahan 
dan Pengendalian Infeksi/PPI), workshops on nosocomial infection have been programmed. Nurses who are known often do not follow the hand hygiene protocol during the five moment, are suggested or mandatory to take the workshops. These workshops aim to provide knowledge and experience about nosocomial infection which will be applied in the hospital settings, therefore nurses are expected to comply in the hand hygiene protocol.

A nurse is a professional when they have the appropriate knowledge, skills, and ethical conduct. The knowledge aspect can always be improved with continuous workshops and education for all employees on all element of infection prevention protocols. ${ }^{11}$ Pencegahan dan Pengendalian Infeksi (PPI) said that they give motivation to their nurses in the hope of increasing hand hygiene compliance and to form a disciplined attitude. This motivation will increase nurses attitude and compliance. The continous monitoring is also expected from the PPI to maintain good hand hygiene compliance of the nurse.

Nur Hidayah Bantul hospital has posters of hand hygiene protocol installed on every nurse ward to increase their nurse's knowledge and compliance. The aim of these posters implies to remind the nurses at all time in case they forget the standard operating procedure and five moments for hand hygiene which they had got during their study or workshops.

During observation, we had not found any posters of five moment hand hygiene protocol in any of the patient's ward. Posters installed to remind the nurses are still insufficient because they were only present in two nurse station. This insufficiency can hinder the nurse from doing the hand hygiene protocol because they might forget the indication or technique of the standard hygiene. ${ }^{12}$

Bivariate analysis regarding nurse's attitude and compliance of doing the hand hygiene protocol showed that $p$-value of attitude variable is $0,003(p<0,05)$, consequently Ha is accepted, and Ho rejected. Those indicated that there is the significant correlation between attitude and hand hygiene compliance, which means that attitude is a risk factor.

Subjects with the poor attitude are in 3,667 higher risks of poor hand hygiene compliance compared to those with the good attitude. The result is statistically significant with $95 \% \mathrm{CI}$ $1,581-8,054 \mathrm{p}$-value $=0,003$, which means that attitude is the factor that affects the implementation of hand hygiene protocol in Nur Hidayah Bantul hospital.

The results of analysis showed a correlation between attitude and hand hygiene compliance because more nurses have the good attitude. Nurses with the positive attitude are more likely to wash their hand according to the protocol. ${ }^{13}$ Nurses with better attitude are, mostly, also those with longer working experience, which include 17 nurses or $63 \%$. The longer the working experience, the stronger their personal experience, thus increase their compliance by doing the hand hygiene protocol. The length of working experience will also determine one's attitude and performance, The more extended of the working experience, the better their attitude because they become more accustomed to their work. ${ }^{14}$

Table 5 shows that most nurses have a good attitude, in which from 15 nurses with the poor attitude only $4(16,7 \%)$ had good compliance, while from 25 nurses with good attitude 20 $(83,3 \%)$ had good compliance. This result shows that good attitude will affect their compliance, even though not every nurses' with the good attitude has good compliance, while the majority of nurse's with poor attitude also had poor compliance.

Attitude will help people reach their goals. Thus they will act positively or negatively, therefore there was a nurse that felt capable or incapable of wash their hand according to the protocols. ${ }^{13}$ Through attitude, we comprehend the process of consciousness that determines concrete action and actions that might be done by individuals in their social life. ${ }^{8}$

RNur Hidayah Bantul hospital has the facilities and infrastructure to support good hand hygiene, for instance running water, soap, 
towel, or disposable tissues. These facilities and infrastructure will help support nurses' attitude to comply with hand hygiene protocol, and they are located in every ward. An attitude might not automatically materialize into behavior or action (over behavior). Because attitude shows an actuality and connotation of the suitability between reaction and stimulus, the facility becomes one of supporting condition for the realization of an attitude into action. ${ }^{10}$ World Health Organization stated that the standard facilities and infrastructures of hand hygiene protocol ares running water, soap, towel or disposable tissue, and alcohol-based antiseptic. ${ }^{15}$ Alcohol-based antiseptic should always be present in health facility. ${ }^{16}$

\section{CONCLUSION}

The present study shows that there is a significant correlation between knowledge and hand hygiene compliance, and there is also a significant correlation between nurses' attitude and hand hygiene compliance. Routine workshops or education are very important for nurses who had or had not attend any workshop in Nur Hidayah Bantul hospital in order to control and prevent the nosocomial infection especially hand hygiene. Increase awareness is needed for every paramedic to maintain and increase knowledge and attitude, as well as hand hygiene compliance correctly and accordingly.

Hopefully, the result of this study can applied as a basis for further research about hand hygiene where other confounding factors can be analyzed, such as the level of education and workshop of nurses in Nur Hidayah Bantul hospital.

\section{CONFLICT OF INTEREST}

We declare that there is no conflict of interest.

\section{Acknowledgement}

Non declare

\section{REFERENCES}

1. Septiari BB. Infeksi nosokomial. Yogyakarta: Nuha Medika; 2012.
2. Menteri Kesehatan Republik Indonesia. Peraturan menteri kesehatan Republik Indonesia nomor 1691/MENKES/PER/ VIII/2011 [Internet]. 1691/MENKES/ PER/VIII/2011 Indonesia; 2011. Available from: http://bprs.kemkes.go.id/v1/ uploads/pdffiles/peraturan/21 PMK No. 1691 ttg Keselamatan Pasien Rumah Sakit. pdf

3. Linda T, Bossemeyer D, McIntosh N. Panduan pencegahan infeksi untuk fasilitas pelayanan kesehatan dengan sumber daya terbatas. In: 1st ed. Jakarta: Yayasan Bina Pustaka Sarwono Prawirohardjo; 2014.

4. Hidayat UM. Buku saku praktikum kebutuhan dasar manusia. Jakarta: EGC; 2004.

5. Fauzia N, Ansyori A, Hariyanto T. Kepatuhan standar prosedur operasional hand hygine pada perawat di ruang rawat inap rumah sakit. Jurnal Kedokteran Brawijaya. 2014;28(1):95-8.

6. Kusmayanti E. Faktor-faktor yang berhubungan dengan infeksi nosokomial pada pengelola limbah medis padat (cleaning service) di RSUD Bangkinang tahun 2016. Jurnal Ners Universitas Pahlawan Tuanku Tambusai. 2017;1(2).

7. Kasmad dkk. Hubungan antara kualitas perawatan kateter dengan kejadian infeksi nosokomial saluran kemih. Jurnal Keperawatan UNDIP. 2007;1(1).

8. Susila dan Susanto. Metodologi penelitian cross sectional. Klaten: Bossscript; 2015.

9. Wawan A, Dewi M. Teori \& pengukuran pengetahuan, sikap, dan perilaku manusia. Yogyakarta: Nuha Medika; 2010.

10. Handojo LH. Pengetahuan perawat tentang infeksi nosokomial di ruang D2 dan D3 Rumah Sakit Adi Husada Undaan Wetan Surabaya. Adi Husada Nursing Journal. 2015;1(1).

11. Notoatmodjo S. Ilmu perilaku kesehatan. Jakarta: PT Rineka Cipta; 2014.

12. Yulianti Rosyidah dan Haryono W. Hubungan tingkat pengetahuan perawat dengan penerapan universal precaution pada perawat di bangsal rawat inap Rumah Sakit PKU Muhammadiyah Yogyakarta. Jurnal Kesehatan Masyarakat. 2011;5(2). 
13. Ernawati E, Rachmi AT, Wiyanto S. Penerapan hand hygiene perawat di ruang rawat inap rumah sakit. Jurnal Kedokteran Brawijaya. 2014;28(1):89-94.

14. Manahulending N, Tandipajung T. Hubungan pengetahuan dan sikap perawat dengan kepatuhan mencuci tangan pada tindakan pemasangan infus di ruang rawat inap Puskesmas Lirung. Buletin Sariputra Universitas Sariputra Indonesia Tomohon. 2015;5(3):7-14.

15. World Health Organizing (WHO). The Apllication of standard precautions in health care fasilities. [Internet]. 2007. Available from: http://www.who.int/csr/resources/ publications/EPR_AM2_E7.pdf

16. Mathuridy RM. Hubungan lama kerja, pendidikan dan motivasi dengan kepatuhan perawat melakukan enam langkah lima moment cuci tangan di ruang ICU RSUD Ulin Banjarmasin. Caring Journal,Sekolah Tinggi Kesahatan Muhammadiyah Banjarmasin. 2015;3(2):50-8. 